\title{
Knowledge and Awareness about Hepatitis B and C Infections among Visitors of the Gastroenterology Clinic of Tertiary Care Centre in Pakistan
}

\author{
Rajesh Mandhwani* Syed Mudassir Laeeq, Muhammad Manzoor ul Haque, Amir Bakhsh, Jawaid Iqbal, \\ Nasir Hassan Luck, Zain Majid
}

Department of Hepatogastroenterology, Sindh Institute of Urology and Transplantation, Karachi, Pakistan.

\begin{abstract}
Background: Hepatitis B and C infections are endemic in Pakistan. The general population has poor knowledge about the HBV vaccine's availability and the modes of transmission for HBV/HCV. Therefore we decided to assess the knowledge of HBV \& HCV infection, their spread and modes of prevention amongst the general population and its association with the ethnic, socioeconomic and educational status.
\end{abstract}

Material and Methods: This cross-sectional analytical study was conducted in Gastroenterology clinic, Sindh Institute of Urology and Transplantation, Karachi, from August 2016 to December 2016. All patients and their attendants of age >18 years visiting GI-OPD were enrolled. A predesigned questionnaire was filled and data was entered in SPSS version 20.0.

Results: Out of 641 respondents, 382 (59.6\%) were males; the mean age of the participants was $38.46 \pm 14.15$ years. Only $44 \%$ respondents were aware about the availability of HBV vaccination. Most of respondents believed that re-usage of syringes, sharing of razors, use of unsterilized dental and surgical instruments can spread these infections. Majority had the misconceptions that these viruses can transmit through handshakes and hugs, smoking, alcohol use, sharing utensils and mosquito bite. Only 23 (3.6\%) respondents had good knowledge. Statistical significance of adequacy of knowledge was noted with profession, monthly family income, education status and ethnicity.

Conclusion: Our study indicates the overall knowledge regarding the modes of transmission and prevention of $\mathrm{HBV} / \mathrm{HCV}$ is very poor among the visitors of GI-clinic from different part of the country. We believe that our study highlights the need to increase the public awareness among general population of HBV/HCV infection in Pakistan. Public awareness seminars should be implemented with special emphasis on mode of transmission of $\mathrm{HBV} / \mathrm{HCV}$ infection and measures to control risk factors.

Keywords: Hepatitis B, Hepatitis C, Disease Prevention, Transmission, Awareness.

\section{BACKGROUND}

Hepatitis can be caused by a group of viruses (hepatitis A, B, $\mathrm{C}, \mathrm{D}$ and $\mathrm{E}$ ) and result into acute and/or chronic infection of the liver. Among these, Hepatitis B, C and D viruses are major causes of morbidity and mortality in terms of liver cirrhosis and hepatocellular carcinoma [1]. The most common routes of transmission of these viruses in the developing countries are from the reused needles and syringes followed by improper sterilization of invasive medical equipment [2]. While in the developed world, the most common route of transmission are intravenous drug use, blood transfusions, via hemodialysis, needle-stick injuries, tattooing, sexual intercourse and peri-natal infections [3]. According to WHO, the worldwide prevalence of $\mathrm{HBV}$ and $\mathrm{HCV}$ was around 257 and 71 million people in 2015 respectively $[4,5]$.

Almost 13 million Pakistani were found to be infected with hepatitis $\mathrm{B}$ and $\mathrm{C}[6,7]$. This is a cause of concern for some countries like Pakistan and according to a research conducted by Pakistan Medical Research Council (PMRC) in 2007, the prevalence of hepatitis B surface antigen (HBsAg) and anti-HCV antibodies in Pakistan was found to be $2.5 \%$ and

*Address correspondence to this author at the Department of Hepatogastroenterology, Sindh Institute of Urology and Transplantation, Karachi, Pakistan. E-mail: mandhwani.rajesh@gmail.com
$4.8 \%$, respectively with a combined infection rate of $\mathrm{HBV}$ and $\mathrm{HCV}$ of $7.6 \%$ was noted. A study done in Pakistan in 2016 by Umar et al. showed the prevalence of $\mathrm{HCV}$ in the adult Pakistani population to be around 6.8\% [8].

Pakistan is a middle income country with limited resources, majority of its population belongs to the lower income group [9] and lives in rural areas where health care facilities are limited [10]. According to Pakistan National Health Accounts 2015-16, total health expenditure as proportion of gross domestic product (GDP) is 3.1\% [11] and Government spends less than optimal $(0.6 \%$ of GDP), merely $15 \%$ on primary and preventive care level [10] Thus it is difficult for the general population to afford the high cost of treating hepatitis and its related complications. But through awareness about $\mathrm{HBV}$ and $\mathrm{HCV}$, the spread of infection could be curtailed. Vaccination is currently the best way to prevent its spread. Unfortunately vaccination for $\mathrm{HCV}$ is currently not available for clinical purposes. However, HBV vaccination is available and it is the most effective to prevent HBV infection. The overall vaccination rate amongst the Pakistani population was merely $13 \%$. The main reason behind the lower vaccine uptake was due to the lack of knowledge about the disease and less awareness about the availability of vaccine [12]. Affordability may not be the hurdle because Federal and Provincial 
Government provide HBV vaccination free of cost through their Prevention and Control of Hepatitis Programs [13, 14]. Therefore through our study, we decided to assess the knowledge of HBV \& HCV infection, their spread and its relation of the ethnicity, profession, socioeconomic and educational status in our population.

\section{MATERIAL AND METHODS}

This cross-sectional analytical study was conducted in the Gastroenterology clinic (GI-clinic), Sindh Institute of Urology and Transplantation (SIUT), Karachi, Pakistan from 01st August 2016 to 31st December 2016. This study was approved by Institutional ethical review board. All patients and their attendants of age more than 18 years visiting GI-clinic for various diseases were subjected to a pre-designed questionnaire, after taking an informed consent. The questionnaire consisted of two parts. The first part one was to assess the socio-demographic status of the participants, including their educational and socioeconomic status. Ethnicity means people with different socio-cultural backgrounds were included like, Punjabi, Sindhi, Pathan etc. Educational status was described as uneducated, primary, matriculation (secondary school), intermediate (higher secondary), bachelor (graduate) and Masters (post graduate). Second part had a set of 21 questions to explore their knowledge on $\mathrm{HBV}$ and $\mathrm{HCV}$ infection and their consequences, mode of transmission and preventive measures as shown in Appendix.

The questionnaire was initially designed in English, and then translated in the country's national language (Urdu) for the ease of the participants. Each correct answer scored one mark and any wrong or question not answered was scored zero. The total score thus obtained by each respondent was converted to percentage and classified as poor $(<50 \%)$, fair $(50-74 \%)$ and good $(\geq 75 \%)$. The mean knowledge and practice scores $(\%)$ for all the respondents were also calculated. Statistical analysis was performed by IBM-compatible Statistical Package for Social Sciences (SPSS) version 20.0 (SPSS Inc., Chicago, IL, USA). Frequencies and percentages were computed for categorical variables while quantitative values were presented as mean \pm standard deviation. Categorical variables were analyzed using the chi-square test. A value of $\mathrm{P}<0.05$ was considered statistically significant.

\section{RESULTS}

A total of 641 persons filled the questionnaire proforma. Baseline demographic characteristics of the respondents are shown in Table 1 . The mean age of the participants was 38.46 \pm 14.15 years, majority of them were males $n=382(59.6 \%)$. Most of respondents that is 482 persons (75.2) were married and only 120 respondents $(18.7 \%)$ received post-secondary education. Majority of the respondents $(502 ; 78.3 \%)$ had a monthly income below Rs.10,000 PKR.
Table 1. Demographic Characteristics of the Respondents.

\begin{tabular}{|c|c|}
\hline Baseline Demographics & $n=641$ (percentages) \\
\hline Age $($ mean $\pm \mathrm{SD})$ & $38.46 \pm 14.15$ years \\
\hline $\begin{array}{l}\text { Gender } \\
\text { Male } \\
\text { Female }\end{array}$ & $\begin{array}{l}382(59.2) \\
258(40.2)\end{array}$ \\
\hline $\begin{array}{l}\text { Marital Status } \\
\text { Married } \\
\text { Single/ Widow }\end{array}$ & $\begin{array}{c}482(75.2) \\
159(24.8)\end{array}$ \\
\hline $\begin{array}{c}\text { Profession } \\
\text { Household } \\
\text { Unemployed } \\
\text { Farmer } \\
\text { Teacher } \\
\text { Health care workers } \\
\text { Others }\end{array}$ & $\begin{array}{ll}174 & (27.0) \\
45 & (7.0) \\
33 & (5.1) \\
15 & (2.3) \\
14 & (2.2) \\
343 & (53.8)\end{array}$ \\
\hline $\begin{array}{c}\text { Ethnicity } \\
\text { Urdu speaking } \\
\text { Sindhi } \\
\text { Baloch } \\
\text { Punjabi } \\
\text { Pathan } \\
\text { Saraiki } \\
\text { Others }\end{array}$ & $\begin{array}{l}194(30.3) \\
182(28.4) \\
69(10.8) \\
64(10.0) \\
64(10.0) \\
22(3.4) \\
46(7.2)\end{array}$ \\
\hline $\begin{array}{l}\text { Education } \\
\text { Masters } \\
\text { Bachelors } \\
\text { Intermediate } \\
\text { Matriculation } \\
\text { Primary } \\
\text { Uneducated }\end{array}$ & $\begin{array}{l}35(5.5) \\
85(13.3) \\
99(15.4) \\
139(21.7) \\
149(23.2) \\
134(20.2)\end{array}$ \\
\hline $\begin{array}{cc}\begin{array}{cc}\text { Monthly Income in PKR* } \\
<10000\end{array} & (<90 \$) \\
10001-20000 & (90-180 \$) \\
20001-30000 & (180-270 \$) \\
>30000 & (>270 \$)\end{array}$ & $\begin{array}{cc}502 & (78.3) \\
97 & (15.1) \\
28 & (4.4) \\
14 & (2.2)\end{array}$ \\
\hline
\end{tabular}

Majority of participants (76.8\%) had a concept that HBV and $\mathrm{HCV}$ infection can lead to serious outcomes and death. More than $>90 \%$ people were of the opinion that these infections are not preventable by non-pharmacological measures. About $56 \%$ participants were unaware about the availability of HBV vaccination. However, $60 \%$ had the misconception that $\mathrm{HCV}$ can also be prevented with vaccination. About 452 (70.5\%) respondents were sure that $\mathrm{HCV}$ infection could be cured if 
diagnosed and treated at earlier stage.

Regarding the transmission of these viruses, it was noted that $475(74.1 \%)$ believed that used syringes and sharing of razors were amongst the main causes of Hepatitis B and C. Almost two third of respondents (438 persons; 68.3\%) also believed that use of unsterilized dental and surgical instrument was also one of the causes. About $126(33 \%)$ males had the misconception in terms of use of infected dental and surgical instruments compared to $76(29.4 \%)$ females $(p=0.218)$ that these contaminated cannot transmit $\mathrm{HBV} / \mathrm{HCV}$ infections. Blood transfusion and organ donation were also considered as risk factors by $460(71.8 \%)$ and $370(57.5 \%)$ respondents respectively. Less than half respondents $(45.2 \%)$ were sure about the spread of these viruses through dialysis machines. Even 379 participants (59.1\%) believed that these infections can be acquired through sexual contact with infected person. Mother-to-infant transmission through child birth was recognized by $52.3 \%$ of respondents. Breastfeeding was considered as a cause by $506(78.9 \%)$ questionnaire takers. Almost $46 \%$ respondents indicated that tattooing or body piercing could also spread the virus. Majority of them (613; 95.6\%) had misconceptions that these viruses can spread through handshakes and hugs. Another false belief was on the matter of sharing daily use items like towels. Almost 2/3rd of respondents $(67.1 \%)$ felt that it was amongst the causes. The respondents also felt that the virus could be contracted by smoking (88.6\%), alcohol use $(81.3 \%)$, sharing utensils $(69.1 \%)$ and mosquito bite $(65.7 \%)$.

Overall the total score was calculated and the total awareness score (knowledge score) was assessed, which was $9.24 \pm 4.40$. On further categorization, majority of them $333(52 \%)$ had poor knowledge, $285(44.5 \%)$ fair and $23(3.5 \%)$ had good as shown in Fig. (1).

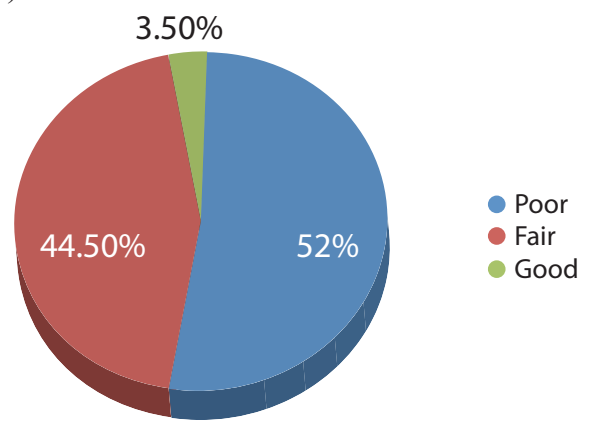

Fig. (1). This Pie Chart Shows the Proportions of Adequacy of Knowledge among Respondents.

Statistical significance of adequacy of knowledge was noted with profession, monthly family income, education status and ethnicity using chi square test as shown in Table $\mathbf{2}$.

Table 2. Factors Associated with Adequacy of Knowledge of HCV/HBV Infection.

\begin{tabular}{|c|c|c|c|c|c|}
\hline \multirow[t]{2}{*}{ Baseline Demographics } & \multirow[t]{2}{*}{$n=641$ (percentages) } & \multicolumn{3}{|c|}{ Adequacy of Knowledge } & \multirow[t]{2}{*}{ Pvalues } \\
\hline & & Poor & Fair & Good & \\
\hline Age $($ mean \pm SD $)$ & $38.46 \pm 14.15$ years & & & & 0.96 \\
\hline$<20$ & $53(8.3)$ & 32 & 20 & 1 & \\
\hline $21-30$ & $171(26.7)$ & 91 & 73 & 7 & \\
\hline $31-40$ & $162(25.3)$ & 85 & 72 & 5 & \\
\hline $41-50$ & $134(20.9)$ & 67 & 61 & 6 & \\
\hline $51-60$ & $78(12.2)$ & 38 & 37 & 3 & \\
\hline$>60$ & $43(6.7)$ & 20 & 22 & 1 & \\
\hline Gender & & & & & 0.24 \\
\hline Male & $382(59.2)$ & 210 & 157 & 15 & \\
\hline Female & $258(40.2)$ & 122 & 128 & 8 & \\
\hline Marital Status & & & & & 0.79 \\
\hline Married & $482(75.2)$ & 247 & 218 & 17 & \\
\hline Single/ Widow & $159(24.8)$ & 86 & 67 & 6 & \\
\hline Profession & & & & & 0.05 \\
\hline Household & $174(27.0)$ & 82 & 89 & 3 & \\
\hline Unemployed & $45(7.0)$ & 24 & 19 & 2 & \\
\hline Farmer & $33 \quad(5.1)$ & 21 & 11 & 1 & \\
\hline Teacher & $15(2.3)$ & 6 & 7 & 2 & \\
\hline Health care workers & $14(2.2)$ & 1 & 11 & 2 & \\
\hline Others & $343(53.8)$ & 192 & 142 & 11 & \\
\hline
\end{tabular}


Table 2. (Continued)

\begin{tabular}{|c|c|c|c|c|c|}
\hline \multirow[t]{2}{*}{ Baseline Demographics } & \multirow[t]{2}{*}{$n=641$ (percentages) } & \multicolumn{3}{|c|}{ Adequacy of Knowledge } & \multirow[t]{2}{*}{$P$ values } \\
\hline & & Poor & Fair & Good & \\
\hline $\begin{array}{c}\text { Ethnicity } \\
\text { Urdu speaking } \\
\text { Sindhi } \\
\text { Baloch } \\
\text { Punjabi } \\
\text { Pathan } \\
\text { Saraiki } \\
\text { Others }\end{array}$ & $\begin{array}{cc}194 & (30.3) \\
182 & (28.4) \\
69 & (10.8) \\
64 & (10.0) \\
64 & (10.0) \\
22 & (3.4) \\
46 & (7.2)\end{array}$ & $\begin{array}{c}80 \\
102 \\
33 \\
33 \\
44 \\
14 \\
27\end{array}$ & $\begin{array}{c}106 \\
75 \\
32 \\
28 \\
19 \\
8 \\
17\end{array}$ & $\begin{array}{l}8 \\
5 \\
4 \\
3 \\
1 \\
0 \\
2\end{array}$ & 0.04 \\
\hline $\begin{array}{c}\text { Education } \\
\text { Masters } \\
\text { Bachelors } \\
\text { Intermediate } \\
\text { Matric } \\
\text { Primary } \\
\text { Uneducated }\end{array}$ & $\begin{array}{c}35(5.5) \\
85(13.3) \\
99(15.4) \\
139(21.7) \\
149(23.2) \\
134(20.2)\end{array}$ & $\begin{array}{l}14 \\
32 \\
44 \\
64 \\
93 \\
86\end{array}$ & $\begin{array}{l}18 \\
47 \\
52 \\
70 \\
54 \\
44\end{array}$ & $\begin{array}{l}3 \\
6 \\
3 \\
5 \\
2 \\
4\end{array}$ & 0.0005 \\
\hline $\begin{array}{cc}\begin{array}{c}\text { Monthly Income in PKR* } \\
<10000\end{array} & (<90 \$) \\
10001-20000 & (90-180 \$) \\
20001-30000 & (180-270 \$) \\
>30000 & (>270 \$)\end{array}$ & $\begin{array}{ll}502 & (78.3) \\
97 & (15.1) \\
28 & (4.4) \\
14 & (2.2)\end{array}$ & $\begin{array}{c}269 \\
50 \\
11 \\
3\end{array}$ & $\begin{array}{c}222 \\
40 \\
14 \\
9\end{array}$ & $\begin{array}{l}11 \\
7 \\
3 \\
2\end{array}$ & 0.03 \\
\hline
\end{tabular}

*Pakistani Rupee.

\section{DISCUSSION}

Majority of participants (76.8\%) in our study had the concept HBV and HCV infection can lead to serious outcomes and death. It was consistent with the findings of Leung CM et al. [15], despite the differences in the educational and socioeconomic status between both the countries. About 450 (70.5\%) respondents knew that $\mathrm{HCV}$ can effectively be treated and cured. This indicates that our general population has insight against the spread of these viruses if properly educated. However, $>90 \%$ people did not know that their transmission can be halted by controlling risk factors. Moreover only $44 \%$ respondents were aware about the availability of $\mathrm{HBV}$ vaccination. According to Ahmed M, et al. [16], HBV infection and related complications can be prevented by HBV vaccination. Furthermore, spread of $\mathrm{HBV} / \mathrm{HCV}$ can be halted by controlling risk factors and by early identification and treatment of index cases. There was a false belief in $60 \%$ of the respondents that HCV can also be prevented with vaccination. Despite technical and clinical advances, HCV vaccination is still not available for clinical purpose. High heterogeneity and mutagenicity of $\mathrm{HCV}$ genome is the major obstacle in the preparation of $\mathrm{HCV}$ vaccine [17].
It is a common belief in Pakistan that parenteral mode of treatment is more powerful and speeds up recovery from any illness [18, 19]. In addition, physicians overprescribe therapeutic injections due to strong financial incentives. Moreover, these injections and drips are most often unsafe and re-used [20]. Abbas et al. [12] noted almost 95\% participants knew that re-usage of syringes and sharing razors can spread these viruses. But in contrast, we noted that only 475 (74.1\%) respondents believed that used syringes and sharing of razors were amongst the main causes of spread of Hepatitis B and C infection. The likely reason behind this difference lies in the fact that the participants of Abbas et al. [12] were relatively better educated. While in our study population, only 120 respondents (18.7\%) received education beyond intermediate level.

The use of unsterilized dental and surgical instruments, unscreened blood products, and dialysis machines were believed to be the cause in spread of these blood borne viruses by majority of the people in our study; 438 persons $(68.3 \%)$, $460(71.8 \%)$ and $290(45.2 \%)$ respectively. Even 370 (57.7\%) respondents considered organ donation as a risk factor for its spread. Use of contaminated instruments and blood products is not uncommon in Pakistan especially in far flung areas where the availability of good health facilities is low [6]. In 
contrast to our results, Batool A, et al. [21] in their survey showed that only $8 \%$ did not know that infected instruments and blood can result in acquisition of this illness. This difference was likely because the participants in their study were dental practitioners with better education and socioeconomic background compared to our respondents.

In our study, 95.6\% participants considered handshakes and hugs lead to acquisition of these viral infections. The respondents also had the belief that the virus could be contracted via smoking (88.6\%), alcohol use $(81.3 \%)$, breastfeeding $(79 \%)$, sharing utensils $(69.1 \%)$ and mosquito bite $(65.7 \%)$. According to Batool A, et al. [21], about $15 \%$ of dentists were of the opinion of that mosquito can spread them. In contrast to participants of 'Hepatitis Awareness Mela' in Pakistan [12], almost 78\% knew that hugs and handshakes could not spread these viruses.

In our study, almost $41 \%$ of respondents were unaware that $\mathrm{HBV} / \mathrm{HCV}$ infections can spread through sexual intercourse. These results were consistent with observed by Chung PW, et al. [22] in adult Chinese population in Hong Kong. However another study done in Pakistan showed that 54\% knew about its transmission via sexual intercourse [23].

If we assess the overall knowledge regarding the modes of transmission and prevention of these blood-borne viral illnesses only 3.6\% participants had adequate knowledge and understanding. People with higher education status, higher monthly income, Baloch, health care workers and teachers were having better knowledge. According to Abiola $\mathrm{AH}$, et al. [24], even certain medical professionals from Nigeria, China, Iran and Pakistan exhibited low knowledge of HBV infection.

The strength of our study was its good sample size of 641 respondents, of different ethinicity, education level and socioeconomic status. There were some limitations of our study; since it was a cross-sectional study we could not assess the effectiveness of public seminars in our population. Moreover, we did not inquire about the HBV vaccination status.

\section{CONCLUSION}

Our study indicates the overall knowledge regarding the modes of transmission and prevention of $\mathrm{HBV} / \mathrm{HCV}$ is very poor among the visitors of GI-clinic from different part of the country. Our participants were of different ethnic, educational and socioeconomic backgrounds. We believe that our study highlights the need to increase the public awareness among general population about HBV/HCV infection in Pakistan. Public awareness seminars should be implemented with special emphasis on the mode of transmission of $\mathrm{HBV} / \mathrm{HCV}$ infection and measures to control risk factors like avoidance of sharing injection needles, toothbrushes or shaving razors. Campaigns should also focus on eliminating misconceptions like sharing utensils \& towels, breastfeeding, smoking and alcohol. These awareness groups should target those persons with lower education, low socioeconomic status and rural areas where the disease is much more prevalent. Such strategies could also be implemented for the neighboring third world countries, since HBV and HCV infections are rampant amongst their population as well.

\section{What is Already Know on This Topic?}

- Inadequate knowledge is one of the most important factors associated with spread of HBV \& HCV infections especially in third world countries.

- Baseline knowledge varies among people of different countries.

\section{What This Study Adds?}

- Our study figures out the baseline knowledge status among general population of Pakistan.

- Misconceptions like sharing utensils \& towels, breastfeeding, smoking and alcohol can be the cause of transmission are also prevalent.

\section{CONFLICT OF INTEREST}

Declared none.

\section{ACKNOWLEDGEMENTS}

Declared none.

\section{REFERENCES}

[1] WHO. Hepatitis: Health topics. 2018; Available at: http://www.emro.who.int/health-topics/hepatitis/index.html

[2] Bosan A, Qureshi H, Bile KM, Ahmad I, Hafiz R. A review of hepatitis viral infections in Pakistan. J Pak Med Assoc 2010; 60(12): 1045-58.

[3] Ashraf S, Ahmad A. Viral hepatitis in Pakistan: Challenges and priorities. Asian Pac J Trop Biomed 2015; 5(3): 190-1. DOI: 10.1016/S2221-1691(15)30004-6

[4] WHO. Hepatitis B. factsheet. 2018; Available at: http://www.who.int/news-room/fact-sheets/detail/hepatitis-b

[5] World Health Organization. Global hepatitis report 2017. 2017; Available at: https://www.who.int/hepatitis/publications/global-hepatitis-report2017/en/

[6] Ahmed W, Qureshi H, Arif A, Alam SE. Changing trend of viral hepatitis--A twenty one year report from Pakistan Medical Research Council Research Centre, Jinnah Postgraduate Medical Centre, Karachi. J Pak Med Assoc 2010; 60(2): 86-9.

[7] Farhat M, Yasmeen A, Ahmad A. An overview of hepatitis B 
and $\mathrm{C}$ in Pakistan. Int $\mathrm{J}$ Microbiol Allied Sci 2014; 1(2): 98-102.

[8] Umer M, Iqbal M. Hepatitis C virus prevalence and genotype distribution in Pakistan: Comprehensive review of recent data. World J Gastroenterol 2016; 22(4): 1684-700. DOI: 10.3748/wjg.v22.i4.1684

[9] WHO. Primary care systems profiles \& performance (Primasys). 2018; Available at : http://www.who.int/alliance-hpsr/projects/AHPSR-Pakistan-061016.pdf

[10] National Health Vision Pakistan 2016-2025. 2016; Available at: http://www.nationalplanningcycles.org/sites/default/files/planning_cycle_repository/pakistan/national_health_visi on_2016-25_30-08-2016.pdf

[11] Pakistan Bureau of Statistics, Government of Pakistan. Pakistan National Health Accounts 2015-16. 2018; Available at: http://www.pbs.gov.pk/content/national-health-accounts-pakistan-2015-16

[12] Abbas M, Hussain MF, Raza S, Shazi L. Frequency and awareness of hepatitis B and $\mathrm{C}$ in visitors of Hepatitis Awareness Mela. J Pak Med Assoc 2010; 60(12):1069-71.

[13] Health and Nutrition. Pakistan Economic Survey 2017-18. 2018; Available at: http:/finance.gov.pk/survey/chapters_18/11-Health.pdf

[14] Health Department, Government of Sindh. Hepatitis free Sindh program. 2012; Available at: from: https://www.sindhhealth.gov.pk/Hepatitis-free-Sindh-Program

[15] Leung CM, Wong WH, Chan KH, et al. Public awareness of hepatitis B infection: A population-based telephone survey in Hong Kong. Hong Kong Med J 2010; 16(6): 463-9.

[16] Ahmed M, Malik N, Ashraf F, Rehman MU, Rashid A. Awareness of Hepatitis 'B' among people of Khyber
Pakhtunkhwa province of Pakistan. J Coll Physicians Surg Pak 2016; 26(5): 443-4.

[17] Naderi M, Gholipour N, Zolfaghari MR, Moradi Binabaj M, Yegane Moghadam A, Motalleb G. Hepatitis C virus and vaccine development. Int J Mol Cell Med 2014; 3(4): 207-15.

[18] Raglow GJ, Luby SP, Nabi N. Therapeutic injections in Pakistan: From the patients' perspective. Trop Med Int Health 200; 6(1): 69-75.

[19] Janjua NZ, Hutin YJ, Akhtar S, Ahmad K. Population beliefs about the efficacy of injections in Pakistan's Sindh province. Public Health 2006; 120: 824-33. DOI: 10.1016/j.puhe.2006.05.004

[20] Janjua NZ, Akhtar S, Hutin YJ. Injection use in two districts of Pakistan: Implications for disease prevention. Int J Qual Health Care 2005; 17(5): 401-8. DOI: 10.1093/intqhe/mzi048

[21] Batool A, Khan MU, Bano KA, Aasim M. Knowledge, attitude and practices of dentists about hepatitis $\mathrm{B}$ and $\mathrm{C}$ infection in Lahore. Pak J Med Res 2012; 51(3): 93-6.

[22] Chung PW, Suen SH, Chan OK, Lao TH, Leung TY. Awareness and knowledge of hepatitis $\mathrm{B}$ infection and prevention and the use of hepatitis B vaccination in the Hong Kong adult Chinese population. Chin Med J (Engl) 2012; 125(3): $422-7$.

[23] Hussain R, Jehan M, Parveen S. Knowledge about hepatitis B and $\mathrm{C}$ among women attending obstetrics and gynaecology clinic at tertiary care hospital. Isra Med J 2014; 6(4): 276-9.

[24] Abiola AH, Agunbiade AB, Badmos KB, Lesi AO, Lawal AO, Alli QO. Prevalence of HBsAg, knowledge, and vaccination practice against viral hepatitis $\mathrm{B}$ infection among doctors and nurses in a secondary health care facility in Lagos state, South-western. Nigeria. Pan Afr Med J 2016; 23: 160. DOI: $10.11604 /$ pamj.2016.23.160.8710 


\section{APPENDIX/SUPPLEMENTARY MATERIAL}

Questions Asked and Their Responses

\begin{tabular}{|c|c|c|c|}
\hline \multirow{2}{*}{\multicolumn{2}{|c|}{ Questions }} & \multicolumn{2}{|c|}{ Response } \\
\hline & & \multirow{2}{*}{$\begin{array}{c}\text { Correct n (\%) } \\
284(44.3)\end{array}$} & \multirow{2}{*}{$\frac{\text { Incorrect } \mathbf{n}(\mathbf{\%})}{357(55.7)}$} \\
\hline 1 & Is there vaccine available for $\mathrm{HBV}$ ? & & \\
\hline 2 & Is there vaccine available for $\mathrm{HCV}$ ? & $254(39.6)$ & $387(60.3)$ \\
\hline 3 & Is it lethal if not treated? & $492(76.8)$ & $149(23.2)$ \\
\hline 4 & Can it be spread by sharing razors and syringes? & $475(74.1)$ & $166(25.9)$ \\
\hline 5 & Can it be spread through blood transfusion? & $460(71.8)$ & $181(28.2)$ \\
\hline 6 & Is HCV curable? & $452(70.5)$ & $189(29.5)$ \\
\hline 7 & Can it be spread through needle stick injury? & 447 (69.7) & $194(303)$ \\
\hline 8 & Can it be spread through surgical or dental treatment? & $438(68.3)$ & $203(31.7)$ \\
\hline 9 & Can it be spread through sexual contact? & $379(59.1)$ & $262(40.9)$ \\
\hline 10 & Can it be spread through organ donation? & $370(57.7)$ & $271(42.3)$ \\
\hline 11 & Can it spread to baby during delivery? & $335(52.3)$ & $306(47.7)$ \\
\hline 12 & Can it be spread through tattooing? & $294(45.9)$ & $347(54.1)$ \\
\hline 13 & Can it be spread through dialysis machine? & $290(45.2)$ & $351(54.8)$ \\
\hline 14 & Can it be spread through mosquito bite? & $220(34.3)$ & $421(65.7)$ \\
\hline 15 & Can it be spread by sharing daily use items? & $211(32.9)$ & $430(67.1)$ \\
\hline 16 & Can it be spread by sharing utensils? & $198(30.9)$ & $443(69.1)$ \\
\hline 17 & Can it be spread through breast-feed? & $135(21.1)$ & $506(78.9)$ \\
\hline 18 & Can it be caused by alcohol? & $120(18.7)$ & $521(81.3)$ \\
\hline 19 & Can it be caused by smoking? & $73(11.4)$ & $568(88.6)$ \\
\hline 20 & Is HCV preventable? & $52(8.1)$ & $589(91.9)$ \\
\hline 21 & Can it be spread through kissing and hugging? & $28(4.4)$ & $613(95.6)$ \\
\hline
\end{tabular}

